\title{
Dermoscopy for common skin problems in Chinese children using a novel Hong Kong-made dermoscope
}

\author{
David CK Luk *, Sam YY Lam, Patrick CH Cheung, Bill HB Chan
}

This article was published on 12 Sep 2014 at www.hkmj.org.

\section{A B S T R A C T}

Objective: To evaluate the dermoscopic features of common skin problems in Chinese children.

Design: A case series with retrospective qualitative analysis of dermoscopic features of common skin problems in Chinese children.

Setting: A regional hospital in Hong Kong.

Participants: Dermoscopic image database, from 1 May 2013 to 31 October 2013, of 185 Chinese children (aged 0 to 18 years).

Results: Dermoscopic features of common paediatric skin problems in Chinese children were identified. These features corresponded with the known dermoscopic features reported in the western medical literature. New dermoscopic features were identified in café-au-lait macules.
Conclusion: Dermoscopic features of common skin problems in Chinese children were consistent with those reported in western medical literature. Dermoscopy has a role in managing children with skin problems.

\section{Hong Kong Med J 2014;20:495-503}

DOI: 10.12809/hkmj144245

DCK Luk *, MSc, FHKAM (Paediatrics)

SYY Lam, MB, ChB, MRCPCH

PCH Cheung, FRCPCH, FHKAM (Paediatrics)

BHB Chan, FRCPCH, FHKAM (Paediatrics)

Department of Paediatrics and Adolescent Medicine, United Christian Hospital, Kwun Tong, Hong Kong

* Corresponding author: davidluk98@hotmail.com

New knowledge added by this study

- This is the first research on dermoscopy in Chinese children.

- Dermoscopic features reported in western medical literature could be identified in Chinese children.

Implications for clinical practice or policy

- Routine use of dermoscopy has a role in managing paediatric skin problems.

\section{Introduction}

Skin complaints are common in both communitybased and hospital paediatric practices. The range of skin problems is diverse, including categories like inflammatory conditions (eg eczema, psoriasis), birthmarks (eg haemangiomas, port-wine stains, melanocytic naevi), infectious skin diseases, and hair and nail problems.

In many situations, the clinical diagnosis of paediatric skin problems is straightforward but masquerading conditions also exist. ${ }^{1,2}$ Although histopathological examination can confirm the clinical diagnosis, skin biopsy in young children may require special arrangements such as sedation. In recent years, the gap between clinical and histopathological examination of skin lesions has been filled by various skin imaging modalities. ${ }^{3,4}$ As a simple, quick, ${ }^{5}$ noninvasive clinical technique, dermoscopy has gained popularity in the examination of skin in western countries. ${ }^{6,7}$ Dermoscopy refers to the examination of skin with a handheld device to reveal surface and subsurface skin structures. This is achieved by an optical system to magnify, illuminate, and remove light flare and reflection from the skin surface. It provides the link between eyeball clinical inspection and histopathological examination. With more than 1500 articles published after its introduction in 1980s, dermoscopy has been established as a routine skin examination technique in many western countries. ${ }^{8}$ As dermoscopy is extremely useful in the diagnosis of malignant melanoma ${ }^{9}$ and is able to reduce the need for skin biopsy, ${ }^{10,11}$ it is most widely used in the management of pigmented skin lesions. Recently, dermoscopic features of a wide range of non-pigmented skin problems have also been reported. ${ }^{12,13}$ With the uncovering of more dermoscopic features, dermoscopy has gained importance in the diagnosis of skin lesions, and its benefits in educating medical students and use in family practice have also been published recently. ${ }^{14-16}$ Medical researches on dermoscopy in Chinese populations, however, have rarely been published. ${ }^{17-19}$ 


\section{以全新香港製造的皮膚鏡為華籍兒童探討常見的 皮膚問題 \\ 陸志剛、林英彥、張志雄、陳衍標 \\ 目的：探討華籍兒童常見皮膚問題的皮膚鏡檢特徵。 \\ 設計：華籍兒童常見皮膚問題的皮膚鏡檢特徵回顧性定性分析病例系 列。 \\ 安排：香港一所分區醫院。 \\ 參與者：2013年5月 1 日至 10 月 31 日期間的皮膚鏡圖像數據庫, 當中 包括 185 名 0 至 18 歲的兒童。 \\ 結果：確認華籍兒童常見皮膚問題的皮膚鏡檢特徵。這些特徵與西方 醫學文獻發表的皮膚鏡檢特徵相似。此外, 研究也找出華籍兒童一些 新的皮膚鏡檢特徵, 例如咖啡牛奶斑。 \\ 結論：華籍兒童常見皮膚問題的皮膚鏡檢特徵與西方醫學文獻發表的 一致。皮膚鏡於處理兒童皮膚問題上具一定作用。}

With the understanding that ethnicity may affect dermoscopic findings, ${ }^{20}$ the aim of this study was to identify dermoscopic features in Chinese children and assess if those are in line with internationally published features.

The clinical use and research on dermoscopy in children worldwide had been limited by both patient factors and equipment factors. Cameramounted dermoscope required lengthy setup and was not user-friendly in busy clinics. In addition, babies and young children might not stay still during the examination. To ensure an efficient dermoscopic examination and a good-quality dermoscopy image capture, a novel device developed by the biomedical engineering team of the Hong Kong Productivity Council was applied. This study evaluated the dermoscopic features of common skin problems in Chinese children using the dermoscopy image database established with the dermoscope.

\section{Methods}

A retrospective analysis of the dermoscopic features of skin lesions of Chinese children (aged 0-18 years) was performed. The study was approved by the local Research Ethics Committee and conducted at the Department of Paediatrics and Adolescent Medicine, United Christian Hospital, Hong Kong, using the dermoscopic image database from 1 May 2013 to 31 October 2013, which contained only cases with symptoms and signs classical for their respective clinical diagnoses. These images were examined by a paediatrician trained in dermoscopy. A two-step algorithm was used to assess dermoscopy images with the first step aiming at differentiating melanocytic from non-melanocytic lesions and the second step on specific pattern analysis. The results of the analysis were categorised according to the clinical diagnoses.

Literature search of the MEDLINE database was performed to identify specific dermoscopic features for each clinical diagnosis. The key words used in the literature search were "dermoscopy, dermatoscopy, dermoscope, dermatoscope". Key words specific to individual clinical diagnosis were used to facilitate the search. It was then assessed if the dermoscopic features of this study corresponded with those from published medical literature.

During the study period, all dermoscopy images were captured by the novel Hong Kongmade dermoscope. It was an all-in-one pocket-size autofocusing polarised digital dermoscope with Wi-Fi and USB connectivity capable of capturing dermoscopy image of all ages including young infants within 5 seconds (Fig). An extensible optic barrel was hinged on the body of the dermoscope so that both gross photos and 10-times magnified dermoscopy photos could be taken. The images were then uploaded to a computerised dermoscopy image database.

\section{Results}

Dermoscopic images of 185 Chinese children (86 boys and 99 girls) suffering from 22 skin conditions were retrieved. The mean age of these children was 5.2 years (range, 2 days to 17 years). The top 12 diagnoses reported (in descending order of frequency) were port-wine stain $(n=42)$, melanocytic naevus $(n=41)$, haemangioma $(n=30)$, café-au-lait macule (CALM; $n=15)$, sebaceous naevus $(n=8)$, viral wart $(n=7)$, atopic dermatitis $(n=6)$, alopecia areata $(n=5)$, cutis aplasia $(n=5)$, psoriasis $(n=4)$, scabies $(n=3)$, and molluscum contagiosum $(n=3)$.

The dermoscopic features of these 12 diagnoses were further analysed. They were grouped into four main disease categories: birthmarks (pigmentary and vascular), infections, hair problems, and

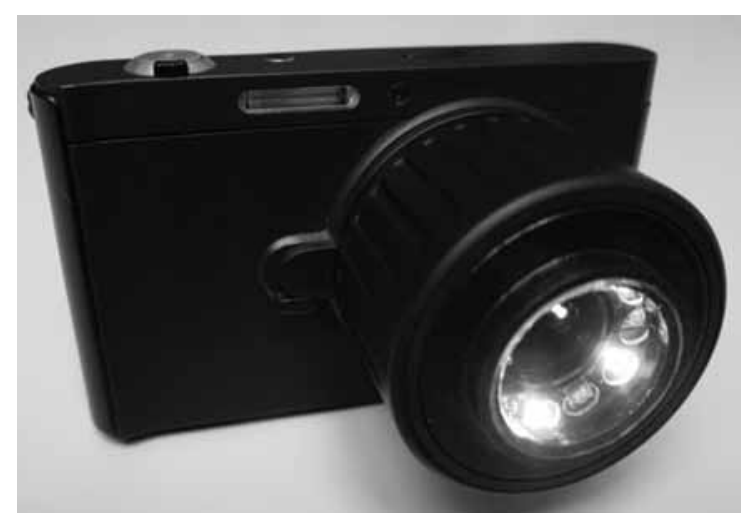

FIG. A novel Hong Kong-made dermoscope 
inflammatory dermatoses. Forty-two dermoscopic features were identified (Table 1).

In the pigmentary birthmark category, there were 41 children with 51 melanocytic naevi (mean age, 7.3 years). The most common dermoscopic pattern of melanocytic naevus was mixed, followed by globular, homogeneous, and reticular. In the mixed pattern naevi, globular-homogeneous was the commonest $(n=13)$, followed by globular-reticularhomogeneous $(n=6)$, reticular-homogeneous $(n=4)$, and globular-reticular $(n=3)$. There were 15 children with CALM (mean age, 3.5 years). All 10 children with facial CALM showed a homogeneous brown patch with perifollicular hypopigmentation. The five children with CALM on neck showed a reticular pattern.

In the vascular birthmark category, there were 42 children with port-wine stains (mean age, 6.5 years) and 30 infants with infantile haemangiomas (mean age, 6 months). For those with port-wine stains, both globular $(n=4)$ and reticular $(n=9)$ vascular patterns were identified but the most common dermoscopic pattern was mixed pattern $(n=29)$ with both globular and reticular components. Among the 30 infantile haemangiomas, 25 had vessels of various morphologies, and red lacunae were noted in 24 . None of the haemangiomas had melanocytic pattern.

In the infectious diseases category, there were seven children with viral warts on hands or feet (mean age, 10.5 years). Thrombosed capillaries presented as black-to-red dots, and papilliform surfaces and interrupted skin lines were identified in all cases. All three children with molluscum contagiosum (mean age, 5 years) showed orifices but vessels and specific vascular patterns could be found in only one case. In the three cases of scabies (mean age, 12.5 years), triangular head, transparent body, and burrows were present.

Patients with patchy alopecia were identified in the hair category. Eight patients had sebaceous naevus (mean age, 8.4 years), with four having yellow dots not associated with hair follicles, three having yellow lobules displacing blood vessels, and one having sebaceous hyperplasia. In the five patients with alopecia areata (mean age, 12 years), dermoscopic features including yellow dots $(n=2)$, black dots $(n=2)$, short vellus hair $(n=4)$, broken hair $(n=4)$, and micro-exclamation mark hair $(n=3)$ were noted. Five patients with cutis aplasia (mean age, 3 years) were featured by a complete lack of skin appendages $(n=5)$ and translucent appearance $(n=4)$.

There were six patients with atopic dermatitis (mean age, 6.5 years) and four patients with psoriasis (mean age, 11 years) in the inflammatory dermatoses category. Atopic eczema was featured by structureless erythema $(n=6)$, scales $(n=6)$, and patchy dotted vessels $(n=4)$ while the psoriasis patients had light red background $(n=4)$, diffuse white scales $(n=3)$, regular dotted vessels $(n=4)$, and glomerular vessels $(n=2)$.

\section{Discussion}

Our study documented the dermoscopic findings of common paediatric skin conditions in Chinese children. In the analysis of the dermoscopy images using a two-step algorithm, the first step was differentiation between melanocytic and nonmelanocytic lesions. This study identified typical melanocytic patterns (globular and reticular pattern ${ }^{21}$ ) in melanocytic naevi, and absence of melanocytic patterns in all haemangiomas. This two-step algorithm analysis of skin lesions confirmed the findings on clinical inspection and provided a standard approach to dermoscopic examination even in difficult cases.

Birthmarks are very common in children. Salmon patches occur in half of the neonates ${ }^{22,23}$ and infantile haemangiomas in one tenth of premature babies, while the prevalence of capillary malformations (port-wine stain) has been reported to be $0.3 \%$ to $2.1 \%{ }^{24,25}$ Within the vascular birthmark category, both port-wine stains and haemangiomas could present as neonatal erythematous patches. As lacunae pattern was commonly identified in haemangiomas but not in port-wine stains, it may serve to differentiate haemangiomas from portwine stains. An early diagnosis of haemangiomas facilitates timely management as some may rapidly proliferate or develop complications in the first few months of life. In our series, the majority of the portwine stain lesions showed a mixed pattern with both globular and reticular components $(n=29 / 42)$ while reticular $(n=9 / 42)$ and globular $(n=4 / 42)$ patterns were less common. The ectatic capillary plexus was situated deeper in the dermis in those with a reticular pattern than those with a globular pattern; this difference may have treatment and prognostic implications on response to laser treatment. ${ }^{13}$ As such, laser treatment strategy aiming at the deeper dermal layer would be required to improve treatment results.

In the pigmentary birthmark category, both congenital and acquired melanocytic naevi were included. The common dermoscopic patterns of globular, reticular, homogeneous, and mixed reported in our series were in line with those reported in the western medical literature. ${ }^{26-29}$ As dermoscopy improves the detection of melanomas, ${ }^{30}$ its use was suggested in the monitoring of congenital melanocytic naevi (CMN), especially the smaller $\mathrm{CMN}^{31-33}$ Sequential digital dermoscopy imaging can also reduce the unnecessary excision of suspicious pigmented skin lesions. ${ }^{34}$ This has been emphasised in children with epidermolysis bullosa who are at risk of developing skin cancers, and in whom overtreatment of the fragile skin should be avoided. ${ }^{35}$ 
TABLE I. Dermoscopic features of the four main disease categories identified in the current study

\begin{tabular}{|c|c|c|c|c|c|}
\hline & Diagnosis (No. & Dermoscopic features (N & patients) & & \\
\hline \multirow{2}{*}{ 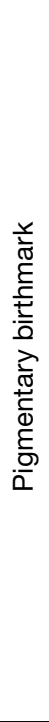 } & 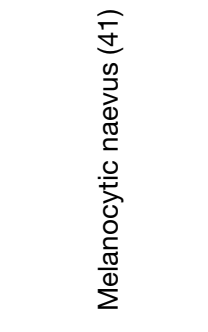 & Mixed (26) & Globular (13) & Homogeneous (6) & 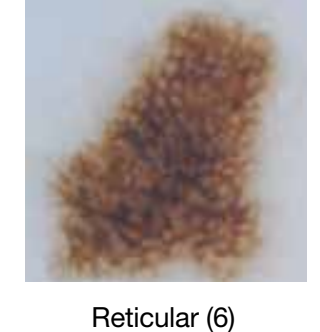 \\
\hline & 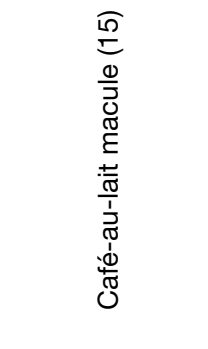 & $\begin{array}{c}\text { Perifollicular } \\
\text { hypopigmentation (10) }\end{array}$ & Reticular (5) & & \\
\hline \multirow{2}{*}{ 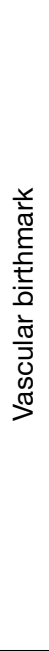 } & 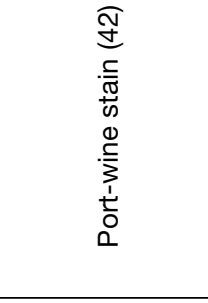 & Mixed pattern (29) & Reticular pattern (9) & Globular pattern (4) & \\
\hline & 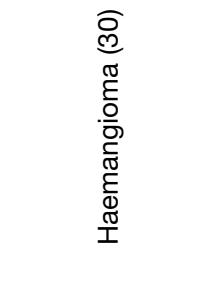 & Red lacunae (24) & Vessels* (25) & & \\
\hline \multirow{2}{*}{ 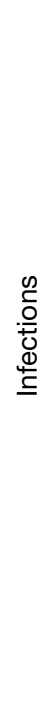 } & 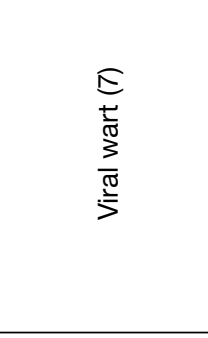 & $\begin{array}{c}\text { Black-to-red dots and } \\
\text { globules (7) }\end{array}$ & Papilliform surfaces $(7)$ & $\begin{array}{l}\text { Interrupted dermatoglyphics } \\
\text { (7) } \\
\end{array}$ & Vessels after trimming (2) \\
\hline & 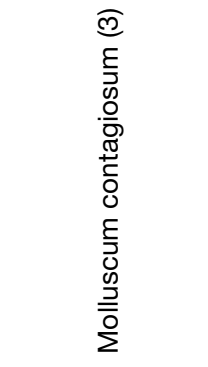 & $\begin{array}{c}\text { Orifices with amorphous } \\
\text { white centre (3) }\end{array}$ & Surrounding vessels (1) & $\begin{array}{c}\text { Specific vascular patterns } \dagger \\
\text { (1) }\end{array}$ & Polylobular (2) \\
\hline
\end{tabular}

* Superficial haemangioma: polymorphous vascular structure with red globular vessels, red circular vessels, red comma-like vessels, red wavy vessels without obvious red linear vessels, and red dilated vessels. Deep haemangioma: polymorphous vascular structures with red linear and red dilated vessels

† Molluscum contagiosum-specific vascular patterns: crown, radial, punctiform, flower, and combination patterns 
TABLE I. (cont'd)

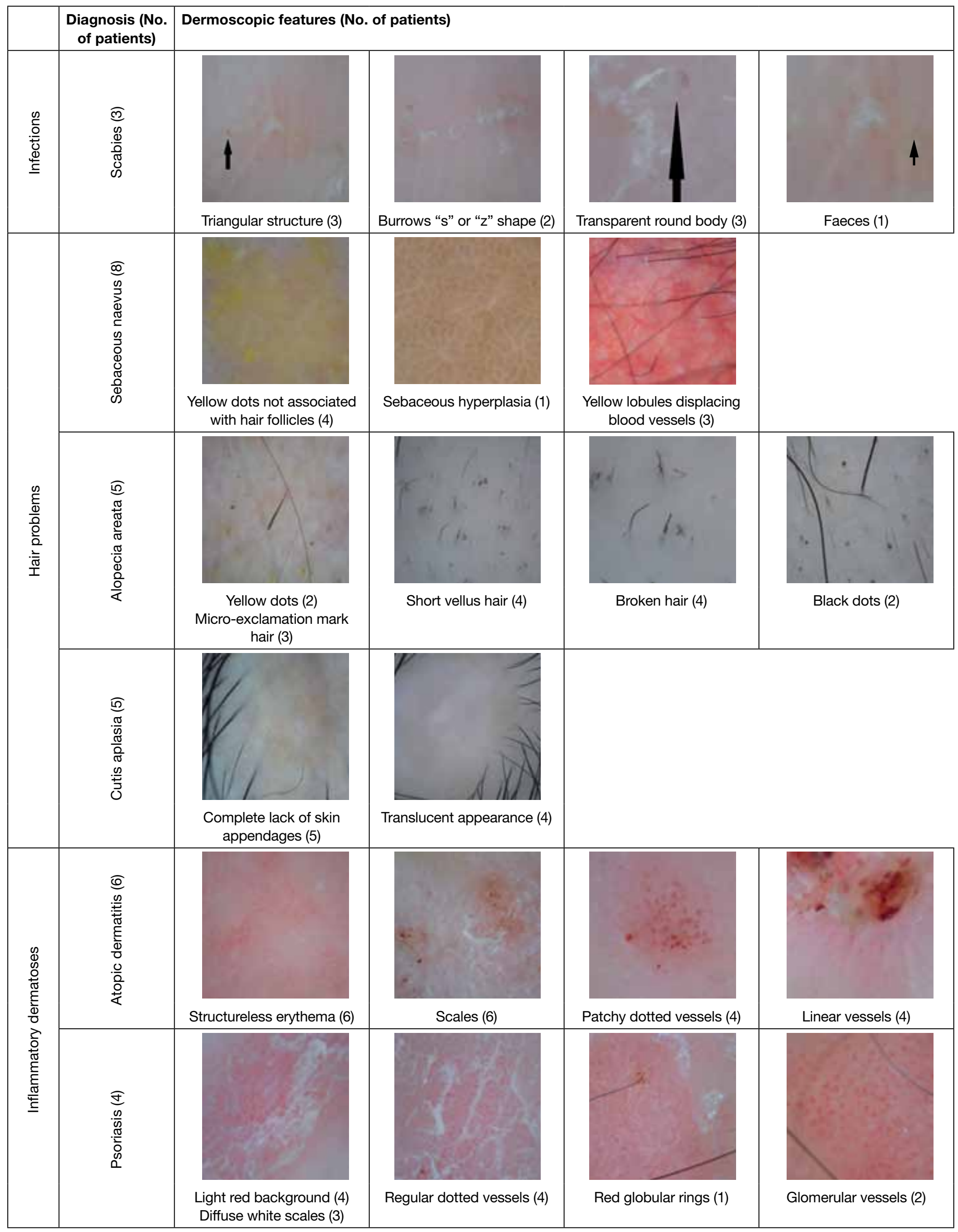


This is the first report of dermoscopic features of CALM in medical literature. It was noted that the dermoscopic patterns of CALM might vary according to the location on the body. All the 10 cases of facial CALM showed homogeneous brown patches with perifollicular hypopigmentation while the five cases of CALM on the neck had a faint brown reticular pattern. As it may be difficult to differentiate CALM from CMN in infancy by inspection, ${ }^{36}$ dermoscopy provides a quick and non-invasive diagnostic tool to guide subsequent management.

In the infectious disease category, all viral warts were on the hands or feet, and all of them showed the classical features of thrombosed capillaries present as black-to-red dots and globules on papilliform surfaces with interrupted skin lines. These findings were consistent with features reported in the medical literature. ${ }^{37}$ The confirmation of the diagnosis of viral wart before initiating treatment is important because acral melanoma, which is more common in Chinese, has been reported to be misdiagnosed as viral wart with disastrous consequences..$^{38-40}$ Moreover, dermoscopy could help guide treatment by identifying residual warty structures or confirming complete resolution of warts. ${ }^{37}$

In our series, there were three children with scabies who had either the classical dermoscopic sign of 'triangular structure ${ }^{41}$ or the round bodies ${ }^{42,43}$ of the scabies mite. The " $\mathrm{z}$ "- or "s"-shaped burrows were also well depicted on dermoscopy in two of them. Dermoscopy is a simple, accurate, and rapid $^{44}$ technique for diagnosing scabies even in inexperienced hands. ${ }^{45}$ In a study involving 756 patients, dermoscopic examination for scabies was found to be $91 \%$ sensitive and $86 \%$ specific. ${ }^{45}$ It greatly enhances treatment decisions ${ }^{45}$ and allows fast introduction of proper treatment. ${ }^{42}$ Diagnosing scabies in children by dermoscopy is child-friendly as it requires no skin scrappings, thus, causing no fear or pain. ${ }^{42}$ In addition, demonstration of scabies mite to patient may foster treatment adherence in both patients and asymptomatic family members. ${ }^{44}$

Molluscum contagiosum is a common skin infection in children ${ }^{46}$ and is highly contagious ${ }^{47}$ with outbreaks reported..$^{48}$ In our three children with molluscum contagiosum, the reported dermoscopic features included orifices with amorphous white centre and polylobular appearance surrounded by vessels. ${ }^{49,50}$ When the typical clinical features of molluscum contagiosum are not apparent, dermoscopy can be helpful for diagnosis. ${ }^{51}$

Three common causes of patchy alopecia in children were reported in this study. For neonates or infants with congenital patchy alopecia, the differentiation between sebaceous naevus and

TABLE 2. Clinical significance of dermoscopic examination in children with skin lesions

\begin{tabular}{|c|c|}
\hline Diagnosis & Clinical significance \\
\hline Melanocytic naevi & $\begin{array}{l}\text { Detection of melanoma } \\
\text { Serial follow-up }\end{array}$ \\
\hline Café-au-lait macule & Early differentiation from congenital melanocytic naevi \\
\hline Port-wine stain & $\begin{array}{l}\text { Early differentiation from haemangioma } \\
\text { Prognosis on response to laser }\end{array}$ \\
\hline Haemangioma & $\begin{array}{l}\text { Timely initiation of appropriate monitoring and treatment } \\
\text { Early planning of treatment }\end{array}$ \\
\hline Viral wart & $\begin{array}{l}\text { Easy and accurate diagnosis } \\
\text { Differentiation from callus and corn } \\
\text { Prevent missing a melanoma } \\
\text { Monitor treatment progress } \\
\text { Confirm treatment success }\end{array}$ \\
\hline Molluscum contagiosum & Confirm clinical diagnosis \\
\hline Scabies & $\begin{array}{l}\text { Rapid confirmation of diagnosis } \\
\text { Early initiation of treatment }\end{array}$ \\
\hline Sebaceous naevus & $\begin{array}{l}\text { Early diagnosis } \\
\text { Monitoring for tumourous change }\end{array}$ \\
\hline Alopecia areata & $\begin{array}{l}\text { Support clinical diagnosis } \\
\text { Assess disease activity } \\
\text { Identify signs of early clinical response and adverse effects to treatment }\end{array}$ \\
\hline Cutis aplasia & $\begin{array}{l}\text { Differentiate from sebaceous naevus } \\
\text { Avoid unnecessary treatment and follow-up }\end{array}$ \\
\hline Atopic dermatitis & $\begin{array}{l}\text { Support clinical diagnosis } \\
\text { Monitor disease severity }\end{array}$ \\
\hline Psoriasis & $\begin{array}{l}\text { Aid clinical diagnosis } \\
\text { Evaluation of treatment outcome }\end{array}$ \\
\hline
\end{tabular}


cutis aplasia may be difficult. ${ }^{52}$ In our study, the dermoscopic features of sebaceous naevi with yellow dots unassociated with hair follicles, sebaceous hyperplasia, and yellow lobules displacing blood vessel $\mathrm{s}^{53}$ were demonstrated. On the other hand, cutis aplasia showed a complete lack of skin appendages and skin translucency. ${ }^{52}$ While no specific treatment is usually needed for cutis aplasia, surgical excision of sebaceous naevi is often advised with its potential for developing into basal cell carcinoma. ${ }^{54}$

The lifetime risk of alopecia areata in the general population is approximately $1.7 \%$ and as many as $60 \%$ of patients with alopecia areata have disease onset before 20 years of age. ${ }^{55}$ The clinical features of hair loss vary with clinical subtypes. ${ }^{56}$ In our series of five children with alopecia areata, black dots, yellow dots, short vellus hair, broken hair, and micro-exclamation mark hairs were noted. These dermoscopic features may be useful clinical indicators in alopecia areata which have both diagnostic and prognostic values. ${ }^{57,58}$

Concerning the inflammatory dermatoses category, clinical similarities exist between atopic dermatitis and psoriasis as both are chronic pruritic scaly erythematous skin conditions. It is known that characteristic dermoscopic vascular patterns facilitate differentiation of psoriasis from atopic dermatitis. ${ }^{59}$ In our study, the patchy dotted vessels ${ }^{60}$ and linear vessels of atopic dermatitis could be differentiated from the red globular rings ${ }^{61}$ and glomerular vessels ${ }^{62}$ of psoriasis.

The clinical significance of dermoscopy in children's skin conditions is summarised in Table 2.

Although various dermoscopic features of skin problems could be identified in this study, it had several limitations. First, the dermoscopy database only contained images captured during routine clinical service when the clinical features were classical of their respective diagnosis. As such, the database was not representative of all common skin problems in children. In addition, with the small case numbers for some of the diseases such as atopic dermatitis and psoriasis, further research is required to confirm our preliminary findings. Moreover, features of skin diseases in children are age-dependent and phase-dependent but these factors were not evaluated in the present study.

\section{Conclusion}

Dermoscopy is a well-established skin examination tool with known dermoscopic features for many diagnoses. Our study confirmed that the dermoscopic features reported in the medical literature could be identified in Chinese children. While the value of dermoscopy in diagnostic, prognostic, and disease monitoring is being unveiled, further studies are required to understand its role in various paediatric skin diseases.

\section{Acknowledgements}

We would like to thank Ms Carol YB Liu and Mr Bryan MK So of Hong Kong Productivity Council and Hong Kong Innovation and Technology Fund for the support on the dermoscopy device for this study.

\section{Declaration}

David CK Luk acted as advisor to Hong Kong Productivity Council on the development of dermoscope prototype. No conflicts of interests were declared by authors.

\section{References}

1. Ng BC, San CY, Lau EY, Yu SC, Burd A. Multidisciplinary vascular malformations clinic in Hong Kong. Hong Kong Med J 2013;19:116-23.

2. Hon KL, Leung TF, Cheung HM, Chan PK. Neonatal herpes: what lessons to learn. Hong Kong Med J 2012;18:602 .

3. Koehler MJ, Lange-Asschenfeldt S, Kaatz M. Non-invasive imaging techniques in the diagnosis of skin diseases. Expert Opin Med Diagn 2011;5:425-40.

4. Sharif SA, Taydas E, Mazhar A, et al. Noninvasive clinical assessment of port-wine stain birthmarks using current and future optical imaging technology: a review. $\mathrm{Br} \mathrm{J}$ Dermatol 2012;167:1215-23.

5. Jaimes N, Dusza SW, Quigley EA, et al. Influence of time on dermoscopic diagnosis and management. Australas J Dermatol 2013;54:96-104.

6. Venugopal SS, Soyer HP, Menzies SW. Results of a nationwide dermoscopy survey investigating the prevalence, advantages and disadvantages of dermoscopy use among Australian dermatologists. Australas J Dermatol 2011;52:14-8.

7. Engasser HC, Warshaw EM. Dermatoscopy use by US dermatologists: a cross-sectional survey. J Am Acad Dermatol 2010;63:412-9, 419.e1-2.

8. Tasli L, Kaçar N, Argenziano G. A scientometric analysis of dermoscopy literature over the past 25 years. J Eur Acad Dermatol Venereol 2012;26:1142-8.

9. Inoue Y, Menzies SW, Fukushima S, et al. Dots/globules on dermoscopy in nail-apparatus melanoma. Int J Dermatol 2014;53:88-92.

10. Argenziano G, Catricalà C, Ardigo M, et al. Dermoscopy of patients with multiple nevi: improved management recommendations using a comparative diagnostic approach. Arch Dermatol 2011;147:46-9.

11. van der Rhee JI, Bergman W, Kukutsch NA. The impact of dermoscopy on the management of pigmented lesions in everyday clinical practice of general dermatologists: a prospective study. Br J Dermatol 2010;162:563-7.

12. Haliasos EC, Kerner M, Jaimes-Lopez N, et al. Dermoscopy for the pediatric dermatologist part I: dermoscopy of pediatric infectious and inflammatory skin lesions and hair disorders. Pediatr Dermatol 2013;30:163-71.

13. Haliasos EC, Kerner M, Jaimes N, et al. Dermoscopy for the pediatric dermatologist, part ii: dermoscopy of genetic syndromes with cutaneous manifestations and pediatric vascular lesions. Pediatr Dermatol 2013;30:172-81.

14. Liebman TN, Goulart JM, Soriano R, et al. Effect of 
dermoscopy education on the ability of medical students to detect skin cancer. Arch Dermatol 2012;148:1016-22.

15. Herschorn A. Dermoscopy for melanoma detection in family practice [in English, French]. Can Fam Physician 2012;58:740-5, e372-8.

16. Chen LL, Liebman TN, Soriano RP, Dusza SW, Halpern AC, Marghoob AA. One-year follow-up of dermoscopy education on the ability of medical students to detect skin cancer. Dermatology 2013;226:267-73.

17. Ye Y, Zhao Y, Gong Y, et al. Non-scarring patchy alopecia in patients with systemic lupus erythematosus differs from that of alopecia areata. Lupus 2013;22:1439-45.

18. Tan C, Min ZS, Xue Y, Zhu WY. Spectrum of dermoscopic patterns in lichen planus: a case series from China. J Cutan Med Surg 2014;18:28-32.

19. Chan G, Ho H. A study of dermoscopic features of pigmented basal cell carcinoma in Hong Kong Chinese. Hong Kong J Dermatol Venereol 2008;16:189-96.

20. de Moura LH, Duque-Estrada B, Abraham LS, Barcaui CB, Sodre CT. Dermoscopy findings of alopecia areata in an African-American patient. J Dermatol Case Rep 2008;2:524.

21. Fortina AB, Zattra E, Bernardini B, Alaibac M, Peserico A. Dermoscopic changes in melanocytic naevi in children during digital follow-up. Acta Derm Venereol 2012;92:4279.

22. Boon LM, Enjolras O, Mulliken JB. Vascular malformations In: Irvine $\mathrm{AD}$, Hoeger $\mathrm{PH}$, Yan $\mathrm{AC}$, editors. Harper's textbook of pediatric dermatology. 3rd ed. Oxford: WileyBlackwell; 2011: 112.1-112.24.

23. Leung AK, Barankin B, Hon KL. Persistent salmon patch on the forehead and glabellum in a Chinese adult. Case Rep Med 2014;2014:139174.

24. Jacobs AH, Walton RG. The incidence of birthmarks in the neonate. Pediatrics 1976;58:218-22.

25. Hidano A, Purwoko R, Jitsukawa K. Statistical survey of skin changes in Japanese neonates. Pediatr Dermatol 1986;3:140-4.

26. Aguilera P, Puig S, Guilabert A, et al. Prevalence study of nevi in children from Barcelona. Dermoscopy, constitutional and environmental factors. Dermatology 2009;218:203-14.

27. Belloni Fortina A, Zattra E, Romano I, Bernardini B, Alaibac M. Clinical and dermoscopic features of nevi in preschool children in Padua. Dermatology 2010;220:53; author reply 54.

28. Scope A, Dusza SW, Marghoob AA, et al. Clinical and dermoscopic stability and volatility of melanocytic nevi in a population-based cohort of children in Framingham school system. J Invest Dermatol 2011;131:1615-21.

29. Zalaudek I, Schmid K, Marghoob AA, et al. Frequency of dermoscopic nevus subtypes by age and body site: a crosssectional study. Arch Dermatol 2011;147:663-70.

30. Haliasos HC, Zalaudek I, Malvehy J, et al. Dermoscopy of benign and malignant neoplasms in the pediatric population. Semin Cutan Med Surg 2010;29:218-31.

31. Nehal KS, Oliveria SA, Marghoob AA, et al. Use of and beliefs about dermoscopy in the management of patients with pigmented lesions: a survey of dermatology residency programmes in the United States. Melanoma Res 2002;12:601-5.

32. Marghoob AA. Congenital melanocytic nevi. In: Marghoob AA, Malvehy J, Braun RP, editors. Atlas of dermoscopy.
London: Informa Healthcare; 2012: 147-58.

33. Rocha CR, Grazziotin TC, Rey MC, Luzzatto L, Bonamigo RR. Congenital agminated melanocytic nevus-case report. An Bras Dermatol 2013;88(6 Suppl 1):170-2.

34. Gulia A, Massone C. Advances in dermoscopy for detecting melanocytic lesions. F1000 Med Rep 2012;4:11.

35. de Queiroz Fuscaldi LA, Buçard AM, Alvarez CD, Barcaui CB. Epidermolysis bullosa nevi: report of a case and review of the literature. Case Rep Dermatol 2011;3:235-9.

36. Bishop JA. Melanocytic naevi and melanoma. In: Irvine AD, Hoeger PH, Yan AC, editors. Harper's textbook of pediatric dermatology. 3rd ed. Oxford: Wiley-Blackwell; 2011: 109.1-109.28.

37. Bae JM, Kang H, Kim HO, Park YM. Differential diagnosis of plantar wart from corn, callus and healed wart with the aid of dermoscopy. Br J Dermatol 2009;160:220-2.

38. Dalmau J, Abellaneda C, Puig S, Zaballos P, Malvehy J. Acral melanoma simulating warts: dermoscopic clues to prevent missing a melanoma. Dermatol Surg 2006;32:1072-8.

39. Rosen T. Acral lentiginous melanoma misdiagnosed as verruca plantaris: a case report. Dermatol Online J 2006;12:3.

40. Burd A, Bhat S. An update on the management of cutaneous melanoma. Hong Kong J Dermatol Venereol 2008;16:143-8.

41. Prins C, Stucki L, French L, Saurat JH, Braun RP. Dermoscopy for the in vivo detection of sarcoptes scabiei. Dermatology 2004;208:241-3.

42. Kamińska-Winciorek G. Entomodermoscopy in scabiesis it a safe and friendly screening test for scabies in children? Acta Dermatovenerol Croat 2012;20:117-9.

43. Executive Committee of Guideline for the Diagnosis, Ishii $\mathrm{N}$. Guideline for the diagnosis and treatment of scabies in Japan (second edition). J Dermatol 2008;35:378-93.

44. Fox G. Diagnosis of scabies by dermoscopy. BMJ Case Rep 2009;2009.

45. Dupuy A, Dehen L, Bourrat E, et al. Accuracy of standard dermoscopy for diagnosing scabies. J Am Acad Dermatol 2007;56:53-62.

46. Netchiporouk E, Cohen BA. Recognizing and managing eczematous id reactions to molluscum contagiosum virus in children. Pediatrics 2012;129:e1072-5.

47. Marsal JR, Cruz I, Teixido C, et al. Efficacy and tolerance of the topical application of potassium hydroxide $(10 \%$ and $15 \%$ ) in the treatment of molluscum contagiosum: randomized clinical trial: research protocol. BMC Infect Dis 2011;11:278.

48. Oren B, Wende SO. An outbreak of molluscum contagiosum in a kibbutz. Infection 1991;19:159-61.

49. Zaballos P, Ara M, Puig S, Malvehy J. Dermoscopy of molluscum contagiosum: a useful tool for clinical diagnosis in adulthood. J Eur Acad Dermatol Venereol 2006;20:4823.

50. Morales A, Puig S, Malvehy J, Zaballos P. Dermoscopy of molluscum contagiosum. Arch Dermatol 2005;141:1644.

51. Mun JH, Ko HC, Kim BS, Kim MB. Dermoscopy of giant molluscum contagiosum. J Am Acad Dermatol 2013;69: e287-8.

52. Neri I, Savoia F, Giacomini F, Raone B, Aprile S, Patrizi A. Usefulness of dermatoscopy for the early diagnosis of sebaceous naevus and differentiation from aplasia cutis congenita. Clin Exp Dermatol 2009;34:e50-2.

53. Kim NH, Zell DS, Kolm I, Oliviero M, Rabinovitz HS. The 
dermoscopic differential diagnosis of yellow lobularlike structures. Arch Dermatol 2008;144:962.

54. Bomsztyk ED, Garzon MC, Ascherman JA. Postauricular cerebriform sebaceous nevus: case report and literature review. Ann Plast Surg 2008;61:637-9.

55. Hon KL, Leung AK. Alopecia areata. Recent Pat Inflamm Allergy Drug Discov 2011;5:98-107.

56. Finner AM. Alopecia areata: clinical presentation, diagnosis, and unusual cases. Dermatol Ther 2011;24:34854 .

57. Rudnicka L, Rakowska A, Olszewska M. Trichoscopy: how it may help the clinician. Dermatol Clin 2013;31:29-41.

58. Inui $S$, Nakajima $T$, Nakagawa $K$, Itami S. Clinical significance of dermoscopy in alopecia areata: analysis of
300 cases. Int J Dermatol 2008;47:688-93.

59. Lallas A, Apalla Z, Tzellos T, Lefaki I. Photoletter to the editor: dermoscopy in clinically atypical psoriasis. J Dermatol Case Rep 2012;6:61-2.

60. Lallas A, Kyrgidis A, Tzellos TG. Accuracy of dermoscopic criteria for the diagnosis of psoriasis, dermatitis, lichen planus and pityriasis rosea. Br J Dermatol 2012;166:1198205.

61. Vázquez-López F, Zaballos P, Fueyo-Casado A, SánchezMartín J. A dermoscopy subpattern of plaque-type psoriasis: red globular rings. Arch Dermatol 2007;143:1612.

62. Micali G, Lacarrubba F, Musumeci ML, Massimino D, Nasca MR. Cutaneous vascular patterns in psoriasis. Int J Dermatol 2010;49:249-56. 